\title{
The Role of Customary Land Ownership in Land-Use Conversion in the Peri-urban of Bukittinggi, Indonesia
}

\author{
Ira Safitri Darwin \\ Bandung Institute of Technology and Universitas Islam Bandung \\ pithok.vie@gmail.com
}

Haryo Winarso

Bandung Institute of Technology

Corresponding Author: hwinarso@pl.itb.ac.id

Denny Zulkaidi

Bandung Institute of Technology

dennyz@pl.itb.ac.id

\begin{abstract}
Taluak is located in the peri-urban area of the city of Bukittinggi, in Agam Regency, West Sumatra, Indonesia. Bukittinggi is rapidly expanding into this peri-urban area. Due to a lack of sound land-use regulations, the growing population and increasing development are encroaching into the peri-urban area. In 1999, the administrative area of Bukittinggi was formally expanded to include some of the surrounding land that had previously been part of Agam Regency. However, although the physical development of the city has encroached into parts of Agam Regency, including Taluak, the communities of the village refused to be administratively included in Bukittinggi. One of their reasons for this refusal is a belief that such urbanization will harm the culture and traditions of the village. This article aims to explain how the communities of Taluak have resisted the formal expansion of Bukittinggi to include them in order to maintain their culture and traditions of land management and to estimate how long such resistance can survive. The article also explains how the process of land conversion in Taluak is carried out, particularly the conversion from rural use into urban use, which creates rurban (rural-urban) areas.
\end{abstract}




\section{Keywords}

customary land - peri-urban land conversion - urban expansion - Nagari Taluak Bukittinggi - West Sumatra

\section{Introduction}

Recent discussions on land-use conversion in the rural areas surrounding fastgrowing cities mostly look at the area close to a big city or metropolitan area(Winarso, Hudalah, and Firman 2015; Nkawae 2006; Hudalah, Winarso and Woltjer 2007). Such studies discuss the transformation of peri-urban areas (Simon 2004; Webster and Muller 2002; Bryant, Russwurm, and McLellan 1982), focusing on the lack of infrastructure (Nkawae 2006; Allen 2003) and the social conflicts that arise. ${ }^{1}$ Recent studies have also focused on the social and economic changes that take place as part of these peri-urban transformations (Pradoto 2012; Winarso, Hudalah, and Firman 2015).

Studies on customary land ownership, on the other hand, tend to discuss whether customary land tenure hinders economic development; ${ }^{2}$ how customary land tenure is converted into modern land ownership; and its administration in Papua New Guinea, Africa, and China. ${ }^{3}$ Less is known about changes to the use of customary land in the peri-urban areas of fast-growing small cities, not to mention the role of customary land ownership rights and cultural values in limiting such changes.

In this article, we study one example of the way in which customary land ownership can delay changes in peri-urban areas. Bukittinggi, with an area of $25.24 \mathrm{~km}^{2}$ (в PS Sumbar 2015) is, economically, the second-most-influential city in West Sumatra after Padang. Bukittinggi is strategically located in the centre of the province, and the city is passed by major national arterial roads that connect the northern and southern parts with the western and eastern parts of Sumatra. It is surrounded by the kabupaten 4 (regency) Agam. This strategic location has contributed to the rapid growth of Bukittinggi (see Figure 1).

1 See Soegijoko \& Firman, 2005; Allen 2003; Bryant, Russwurm, and Mclellan 1982.

2 See, for instance, studies in Papua New Guinea by Gershenberg 1971; Sukot 2010; Tegnan 2015.

3 See Benda-Beckmann and Benda-Beckmann 2004; Knight 2010; Mugambwa 2007; Sylivester 2013; Yaping and Min 2008; Akrofi 2013.

4 Indonesia's administrative structure has two levels of autonomous regions: the province (provinsi) and the district (the municipality, or kotamadya, for urban areas and the regency, or kabupaten, elsewhere). The district level is further subdivided into the kecamatan (subdistrict) and the kelurahan in urban areas, and the desa, or village, in rural areas. 

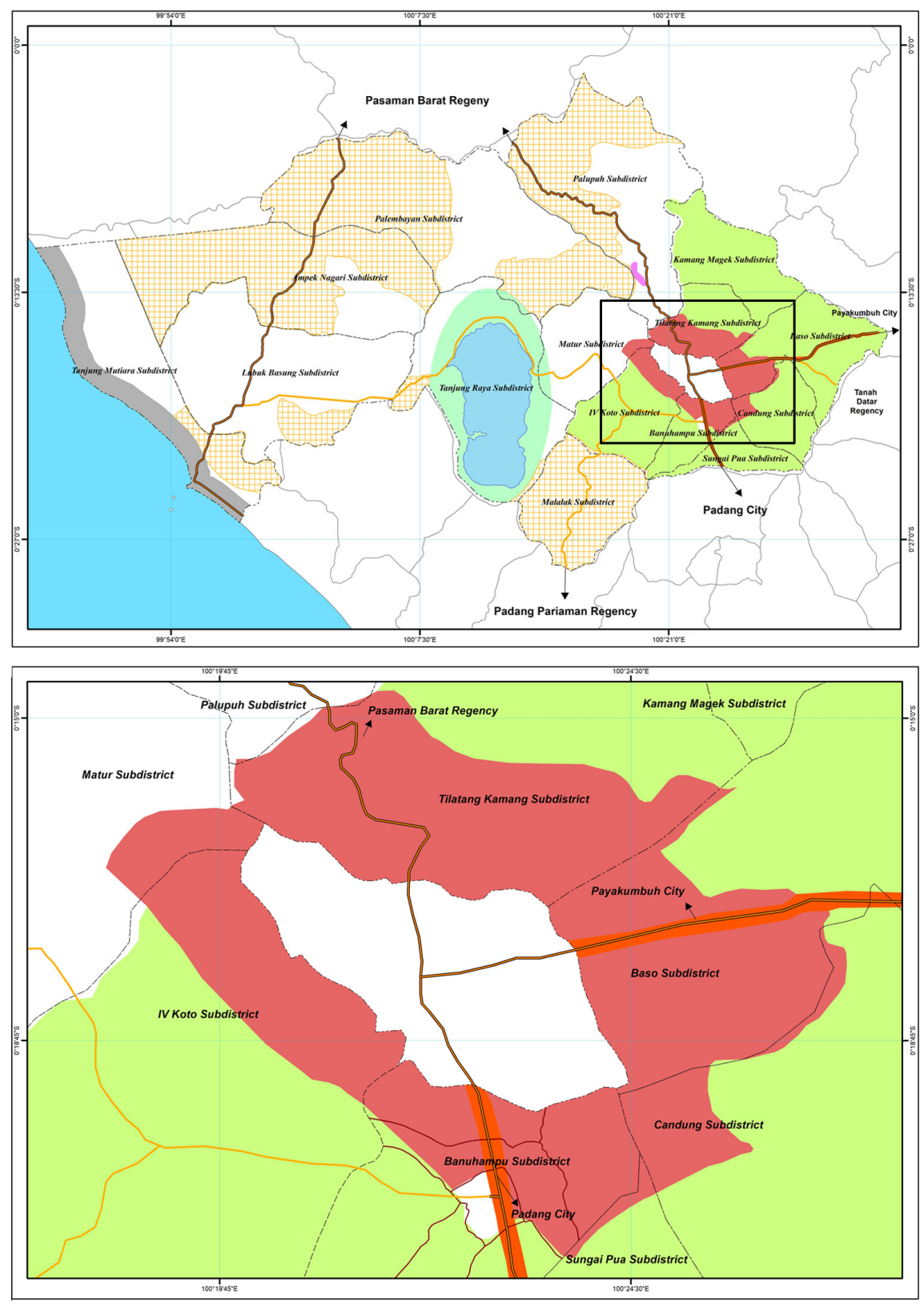

FIGURE 1 The location of Agam Regency RENCANA TATA RUANG WILAYAH-RTRW (SPATIAL PLAN) OF AGAM REGENCY IN 2010 
West Sumatra is ethnically a Minangkabau area. What is unique about this community is that they embrace a matrilineal culture in which kinship follows the maternal rather than the paternal line. ${ }^{5}$ Moreover, in West Sumatra, all lands are supposed to be under tanah ulayat (customary land) ownership status, wherein customary law regulates the use, trade, and inheritance of the land.

To accommodate the rapid urban development of Bukittinggi, a formal administrative expansion of the city into the territory of the surrounding Kabupaten Agam was stipulated by Government RegulationNo. 84 in $1999 .{ }^{6}$ This regulation expanded Bukittinggi to an area of $14,529.90$ ha $\left(145.299 \mathrm{~km}^{2}\right)$, almost five times larger than the original area of the city. However, this regulation was challenged by the communities of Kabupaten Agam for three reasons. Firstly, the regulation is legally void because the communities and the ninik mamak (traditional leaders) were not consulted during its preparation. ${ }^{7}$ Secondly, as the area bordering Bukittinggi is a significant contributor to the regional revenue of Kabupaten Agam, its inclusion in the administrative area of Bukittinggi would eliminate potential revenue generation for Kabupaten Agam. Thirdly, it was feared that urbanization, and thus modernization, would erode the cultural and traditional values of the community. Liputan6.com (2002), a national online newspaper, reported that hundreds of residents of Agam Regency, West Sumatra, demonstrated in front of the West Sumatra governor's office, demanding that the governor of West Sumatra, Zainal Bakar, urge the central government to cancel the enactment of Government Regulation No. 84 of $1999 .^{8}$

One of the community groups that disagrees with the inclusion of their area in the administrative expansion of Bukittinggi is the community in Kecamatan (sub-district) Banuhampu. This is one of several sub-districts in the peri-urban area of Bukittinggi, which is designated in the Rencana Tata Ruang Wilayah-

5 According to scholars, the Minangkabau tribe is considered the largest matrilineal tribe in the world. See R. Sankari, 'Masyarakat matrilineal terbesar di dunia ada di Sumatra Barat'; Benda-Beckmann and Benda-Beckmann 2004; Evers 1975. In 2010 the number of members of the Minangkabau tribe totalled 6,464,713 (вPs Indonesia 2010).

6 Peraturan Pemerintah Republik Indonesia Nomor 84 Tahun 1999 tentang Perubahan Batas Wilayah Kota Bukittinggi dan Kabupaten Agam.

7 The Ninik Mamak is an adat institution consisting of several penghulu (tribal chiefs) who come from the various clans that exist among the tribes of the Minangkabau. The position of the penghulu is held by an older Minangkabau male who is considered capable of leading wisely; ninik mamak can also mean individual member of the institution.

8 'Ratusan warga Agam menolak perluasan Kota Bukittinggi', Liputan 6, 31-3-2002. 
RT RW (Spatial Plan) of Kabupaten Agam as part of both the Area Strategis Perbatasan (Strategic Border Area) and the Area Strategis Timur-Barat (East-West Strategic Area). This strategic location has created rapid growth in Kecamatan Banuhampu, which is especially evident in the levels of land conversion from rural to urban use along the national arterial road to Padang, the biggest city in West Sumatra.

Nagari Taluak IV Suku (hereafter Taluak) is a nagari in Kecamatan Banuhampu that borders Bukittinggi. Outside the municipal (urban) territories, a nagari is considered the smallest unit of local government in the province of West Sumatra. Because of the rapid physical development along the national arterial road, the peri-urban area between Bukittinggi and Taluak has become built up, a condition labelled as desakota by McGee (1991).

As has been discussed elsewhere, ${ }^{9}$ physical urban expansion encroaches on, and converts agricultural land into, urban land, transforming the socioeconomic status of the community.Surya (2016), McGee (1991, 2014), and Russwurm (1975) all assert that the land-use conversion on the inner fringe will be faster than that on the outer fringe, thus creating a rurban (rural-urban), or desakota, space that acts as a transition area between the city and the village. In the case of Taluak, the expansion of Bukittinggi has transformed the formerly agricultural area that supplied vegetables to Bukittinggi into an urbanized area of settlement, trade, and services.

In Taluak, some of the customary land tenures have thus been converted into statutory land rights. The customary land right (hak ulayat) is a land ownership right that is regulated by the Land Law No. 5 of $1960 .{ }^{10}$ The West Sumatra provincial government enacted Perda Provinsi (or Provincial Regulation) No. 16/2008 on communal land tenure in recognition of these communal rights at a regional level. Tanah ulayat refers to all land within the jurisdiction of a nagari and is managed according to adat (customary) law. Use of the term ulayat is typical of the Minangkabau people (Tegnan 2015). Land held under customary land rights, often referred to as tanah ulayat, is defined as tanah pusako (inheritance land) and owned by the community; the right to this land is governed by customary law.

The focus of this study is the unique system of land ownership, authorization, and arrangement in Taluak in West Sumatra, especially in the context of the expansion of Bukittinggi. This unique system is influenced by matrilineal cultural values, which means that all lands in West Sumatra, including tanah

$9 \quad$ Nas 1984; Sudrajat 2016; Winarso, Hudalah, and Firman 2015; Woltjer 2014.

10 Undang-Undang Pokok Agraria Nomor 5 Tahun 1960. 
ulayat, tanah ulayat rajo, tanah ulayat nagari, tanah ulayat suku, and tanah ulayat kaum are owned by the community. ${ }^{11}$ Against the above background, this study explores how customary tenures and cultural values affect the landuse conversion in the peri-urban area surrounding the fast-growing small city of Bukittinggi and accommodate the continuously increasing demand for land for urban uses.

\section{2}

\section{Methods}

This article aims to explain how the communities of Taluak in the peri-urban area of Bukittinggi are protecting their culture, traditions, and customary lands from the modernization caused by the city's formal and informal expansion and urbanization; it also endeavours to estimate how long this protection will last. The article explains how land governance in Taluak is carried out, particularly with regard to managing the conversion of land from rural to urban use, where it creates rurban (rural-urban) areas.

The study uses a qualitative approach in interpreting the cultural values and a quantitative approach in interpreting satellite images to estimate the pace of encroachment. The study of cultural values is intended to uncover changes in the phenomenon of land management in Taluak and the influence of matrilineal values on contemporary urban development. The methodology consists of semi-structured interviews with stakeholders including landowners, tribal chiefs, businesspeople, Taluak community members, and investors, using the method of snowball-sampling. In all, two women were interviewed. The first round of interviews was conducted from January to June 2017 through several means of communication, including face-to-face interviews as well as telephone and WhatsApp communication for follow-up questions. Eight individuals were formally interviewed, having responded to letters requesting their input. In addition, several randomly selected people, whom we met in a café, were interviewed informally (without a prior, formal request letter). These people were only given the explanation that we wanted to ask some questions about land in Bukittinggi. The second round of formal interviews took place in November 2018 and involved four ninik mamak and two recent land purchasers; their answers confirmed the results of the first round of interviews. Snowballing questionnaires were also distributed through Survey Monkey to

11 Achir 2011; Asri 2001; Hadjerat 1947; Irwandi 2010. See also 'Tanah ulayat dan pemanfaatannya', Perda Provinsi Sumatera Barat No. 16 Tahun 2008. 
landowners along the arterial road in Taluak to better understand their recent land-ownership status and the reasons why they had sold or bought land in the area.

Satellite images were studied to discover the extent of the expansion of Bukittinggi and of the land conversion in Taluak between 2006 and 2016. The results were later confirmed using field observations.

Taluak was selected as the study area because it borders Bukittinggi. The subdistrict shows significant growth, as is evident from its Village Development Index (Indeks Pembangunan Desa) score. In 2015, Taluak scored 0.753 on the index, which is categorized as advanced (Hamidi et al. 2015). Meanwhile, the village's score on the Human Development Index was 69.84, a medium-level result (BPS Agam 2016). Based on the satellite image provided by Bing, the area of Taluak is 403 ha, which is slightly larger than the 341 ha given as the size by the formal data of the Badan Pusat Statistic-BPs (вPS-Central Bureau of Statistics). Taluak had a population of 6,041 in 2015. This equals 15 persons per hectare (B PS Agam 2016), which is a very low population density. Taluak consists of several dusun (hamlets): Jorong Jambu Aia, Kapeh Panji, and Taluak IV Suku. Figure 2 below shows the area of Taluak relative to Bukittinggi.

\section{3}

\section{The Encroachment of Bukittinggi into Taluak IV Suku}

It is widely known that urban development in the hinterland of a city will convert agricultural areas into non-agricultural areas, especially on the inner fringe(Winarso, Hudalah, and Firman 2015; Woltjer 2014). This is also true in the case of the encroachment of Bukittinggi into Taluak, which is located on the inner fringe.

Taluak is closer to Bukittinggi $(3.8 \mathrm{~km})$ than to the capital of the sub-district of Banuhampu, to which it belongs. Bukittinggi's expansion to the south is natural, since the southern region is geographically flatter than in any other direction and is more accessible due to the presence of a national arterial road. This expansion has caused the land to be converted from rural to urban use and the ownership status of the land to have been converted from customary tenure into modern, individual tenures, especially along the arterial road connecting Bukittinggi and Padang Luar, a small town in the sub-district of Banuhampu that is located 5 to $6 \mathrm{~km}$ to the south. As expected, the population of Taluak has also increased, although it still has a low growth rate (see Figure 3).

An analysis based on Bing satellite images shows that over the last ten years (2006-2016) land conversion from agricultural to non-agricultural use has been slow; during this period the area covered by agricultural land had decreased 

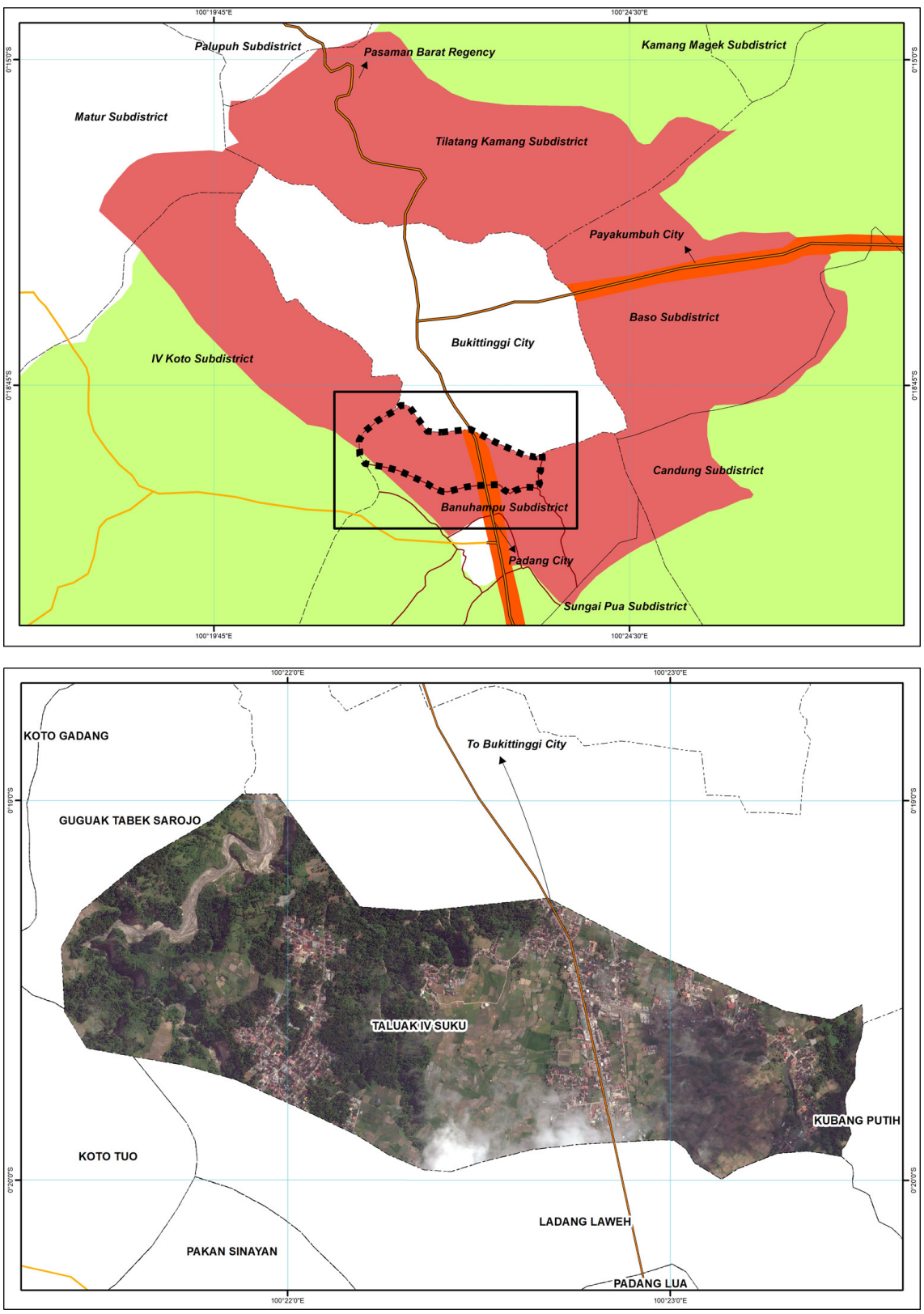

FIGURE 2 (a) Taluak IV Suku and Bukittinggi; (b) Taluak IV Suku administration area (A) SPATIAL PLAN OF AGAM DISTRICT 2010; (B) BING MAP SATELLITE IMAGE 2016 


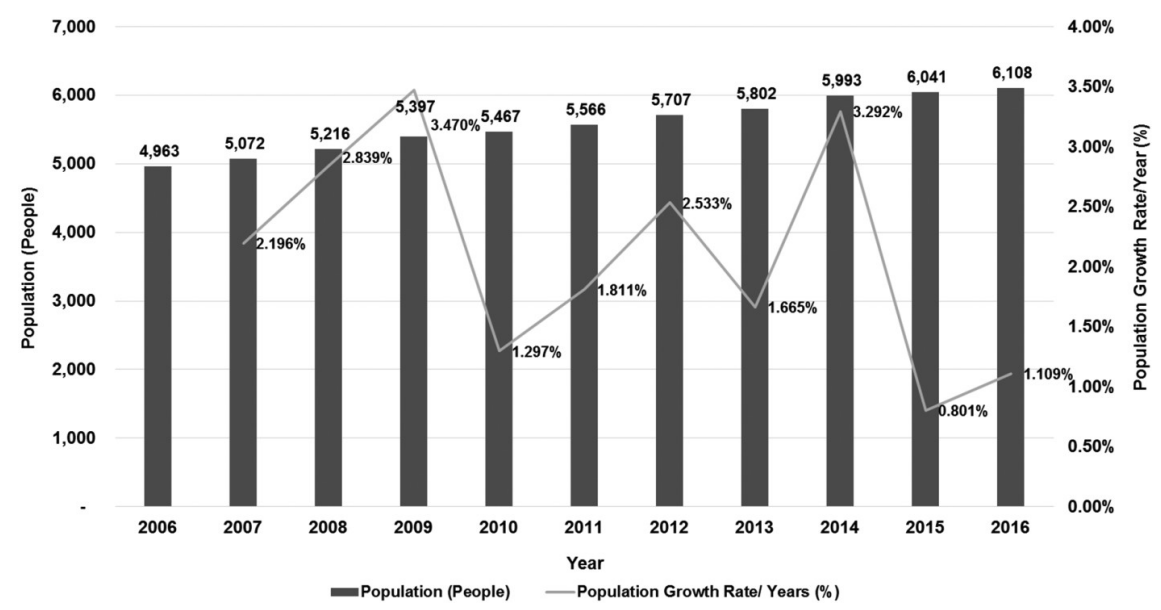

FIGURE 3 Population of Taluak IV Suku, 2006-2016

KECAMATAN BANUHAMPU DALAM ANGKA, 2010, 2011, 2015-, 2017;

MONOGRAFI NAGARI TALUAK IV SUKU, 2007-2009, 2012

by 3.7 ha. This means that the rate of change was around $0.24 \%$ per year. Along the national arterial road, however, the rate of land conversion from agricultural to non-agricultural use was much higher than in Taluak as a wholearound $2.5 \%$ per year.

Closer observations in the field also show significant conversions from traditional housing into two-to-three-storey buildings for trades and services, which has thus increased the density of land use in the area along the road connecting Bukittinggi and Padang Luar. The area used for housing has also increased. Almost $90 \%$ of the houses in this corridor have been converted into buildings for trades and services in the form of shops and restaurants (see Table 2).

If the speed of change is constant, within ten years, around $19 \%$ of the land in Taluak will have been converted into urban-use land; this will be most of the land along the arterial road. Detailed information about the land-use conversion in Taluak during the period 2006-2016 can be seen in Tables 1 and 2 and Figures 4 and 5 .

\section{Customary Landownership}

The conversion of agricultural land into land used for urban purposes is complicated by the idiosyncratic land tenure system of the Minangkabau. The matrilineal culture of the Minangkabau has arguably influenced urban development in West Sumatra; this is particularly visible in land-related develop- 
TABLE 1 Land-use changes in Taluak IV Suku, 2006-2016

\begin{tabular}{|c|c|c|c|c|c|}
\hline \multirow[b]{2}{*}{ Land use } & \multicolumn{2}{|c|}{ Land area $(\mathrm{Ha})$} & \multicolumn{2}{|c|}{ Percentage (\%) } & \multirow{2}{*}{$\begin{array}{l}\text { The rate of land- } \\
\text { use change/year } \\
(\%), 2006-2016\end{array}$} \\
\hline & 2006 & 2016 & 2006 & 2016 & \\
\hline Scrubland, river boundary & 165.09 & 165.96 & $40.92 \%$ & $41.14 \%$ & $0.05 \%$ \\
\hline \multicolumn{6}{|l|}{ Built-up area } \\
\hline * National transport corridor & 6.64 & 7.06 & $1.65 \%$ & $1.75 \%$ & $0.62 \%$ \\
\hline * Out of national transport corridor & 68.53 & 71.82 & $16.99 \%$ & $17.80 \%$ & $0.48 \%$ \\
\hline Agricultural areas & 151.67 & $147 \cdot 97$ & $37.6 \circ \%$ & $36.68 \%$ & $-0.24 \%$ \\
\hline River & 11.48 & 10.61 & $2.85 \%$ & $2.63 \%$ & $-0.76 \%$ \\
\hline Total & 403.41 & 403.41 & $100.00 \%$ & $100.00 \%$ & \\
\hline
\end{tabular}

DIGITIZED FROM BING MAP SATELLITE IMAGE IN 2006 AND 2016, 2017

TABLE 2 Land-use changes along nasional transport corridor (depth $100 \mathrm{~m}$ left-right) in Taluak, IV Suku 2006-2016

\begin{tabular}{|c|c|c|c|c|c|}
\hline \multirow[b]{2}{*}{ Land use } & \multicolumn{2}{|c|}{ Land area (Ha) } & \multicolumn{2}{|c|}{ Percentage (\%) } & \multirow{2}{*}{$\begin{array}{l}\text { The rate of land } \\
\text { use change/year } \\
(\%), 2006-2016\end{array}$} \\
\hline & 2006 & 2016 & 2006 & 2016 & \\
\hline Fishponds & 1.36 & 0.99 & $5.46 \%$ & $3.99 \%$ & $-2.68 \%$ \\
\hline Fields & 2.30 & 1.06 & $9.25 \%$ & $4.26 \%$ & $-5 \cdot 39 \%$ \\
\hline Agriculture & 3.46 & 2.60 & $13.91 \%$ & $10.47 \%$ & $-2.47 \%$ \\
\hline Scrubland & 1.41 & 1.27 & $5.67 \%$ & $5.09 \%$ & $-1.03 \%$ \\
\hline Built-up area & 6.64 & 7.06 & $26.70 \%$ & $28.37 \%$ & $0.62 \%$ \\
\hline Streets & $9 \cdot 70$ & 11.90 & $39.01 \%$ & $47.82 \%$ & $2.26 \%$ \\
\hline Total & 24.88 & 24.88 & $100.00 \%$ & $100.00 \%$ & \\
\hline
\end{tabular}

DIGITIZED FROM BING MAP SATELLITE IMAGE 2006 AND 2016, 2017 
ment. In the Minangkabau matrilineal system, tanah ulayat equates to harato pusako (harta pusaka in Indonesian), meaning ancestral/patrimonial property (Achir 2011). Almost all land in West Sumatra has tanah ulayat status. In customary beliefs, tanah ulayat is land reserved for the community. It is prohibited to sell or pawn it, except under the following conditions: 1) Maik tabujua ditangah rumah (literally: if there is a corpse in the house);2) Membangkikbatang tarandam (literally: if necessary to bring up submerged stems, that is, to educate the youth); 3) Gadih gadang indak balaki (literally: if there is a woman who has not married); 4) Rumah gadang katirisan (literally: if the family house is broken) (Achir 2011; Navis 1984). These conditions show that, in theory, tanah ulayat can only be sold or pawned if there is an urgent need to pay the burial costs for a family member; to support the education of, or pay for the wedding of, a poor family member; or to refurbish the family house.

Tanah ulayat is inherited by the female members of a (sub)lineage or clan, but the ninik mamak, or the male heads of the (sub)lineages and clans, coordinate and control the utilization of the land through a democratic deliberation with the members of the kin group, based on Minangkabau customary law (as stipulated in Provincial Regulation No. 16/2008). The rules pertaining to customary land ownership set out above are more or less a textbook version. The rules are based on oral tradition, which then informs actual practice. In reality, forms of land ownership can be more diverse and also problematic, probably more so in cities (Evers 1975; Colombijn 2006).

Traditionally, the tanah ulayat has had a social as well as an economic function. It can be village land or territory and includes the land, forestry, water, and minerals. ${ }^{12}$ Tanah ulayat can be used for housing or cultivation, or can be land that is reserved for the next generation's use. More recently, however, there has been agreement among the community that tanah ulayat can be used for the development of the village. The procedures for the transfer of ownership from customary to individual or state land for public purposes are regulated by local by-law $16 / 2008 .{ }^{13}$

More recently, in 2012, the Indonesian government enacted Law No. 2 of $2012^{14}$ concerning land acquisition for public purposes. This law states that if

\footnotetext{
12 Village land refers to the administrative boundary of a village, while territory may include the land (empty/vacant land), forests, water such as small pond or a creek, and minerals in the territory.

13 Perda Provinsi Sumatera Barat No. 16 Tahun 2008 tentang Tanah Ulayat dan Pemanfaatannya.

14 Undang-Undang Nomor 2 Tahun 2012 tentang Pengadaan Tanah bagi Pembangunan untuk Kepentingan Umum.
} 

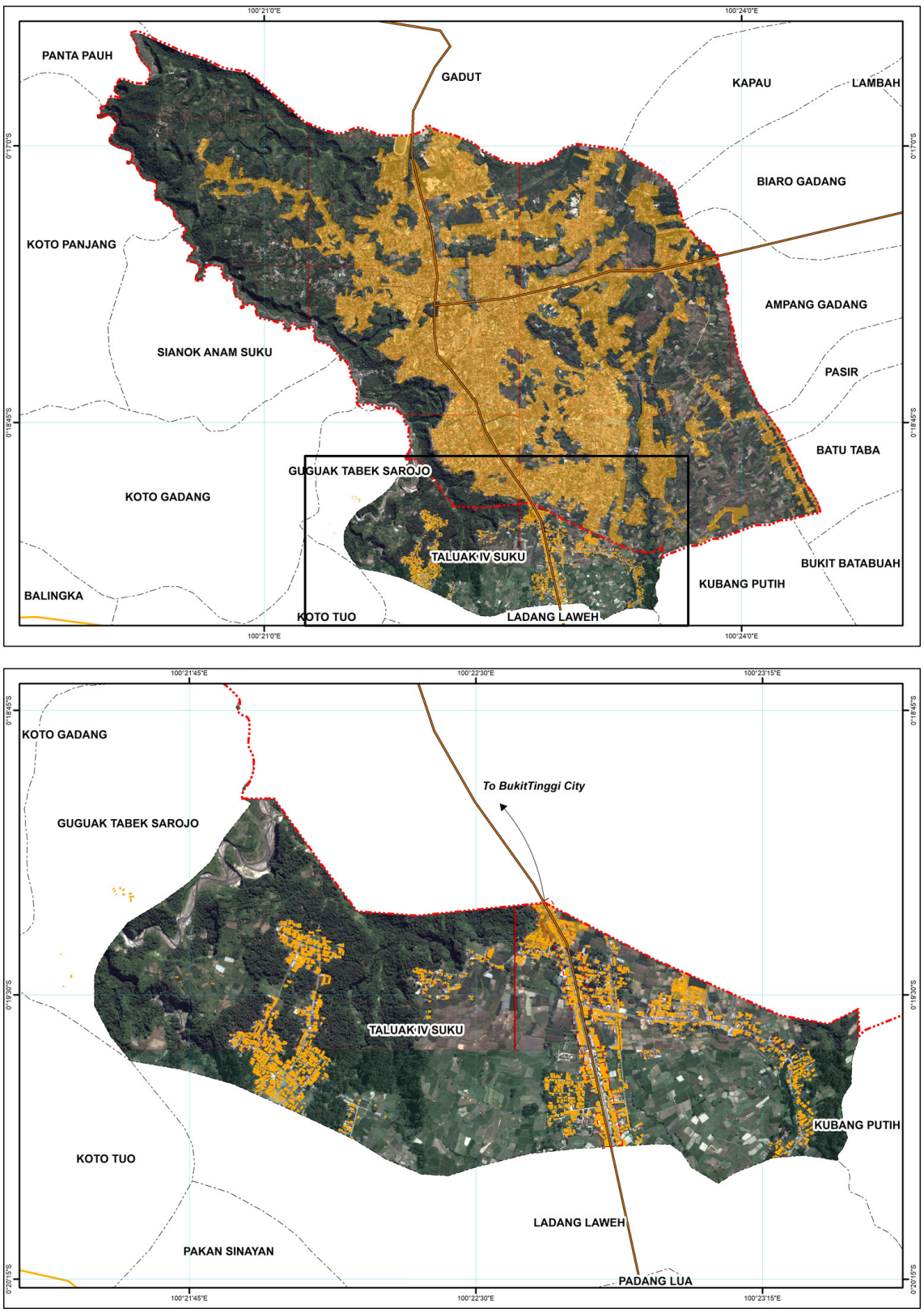

FIGURE 4A Bukittinggi expansion and built-up area in Taluak IV Suku, 2006 DIGITIZED FROM BING MAPS SATELLITE IMAGE IN 2006 

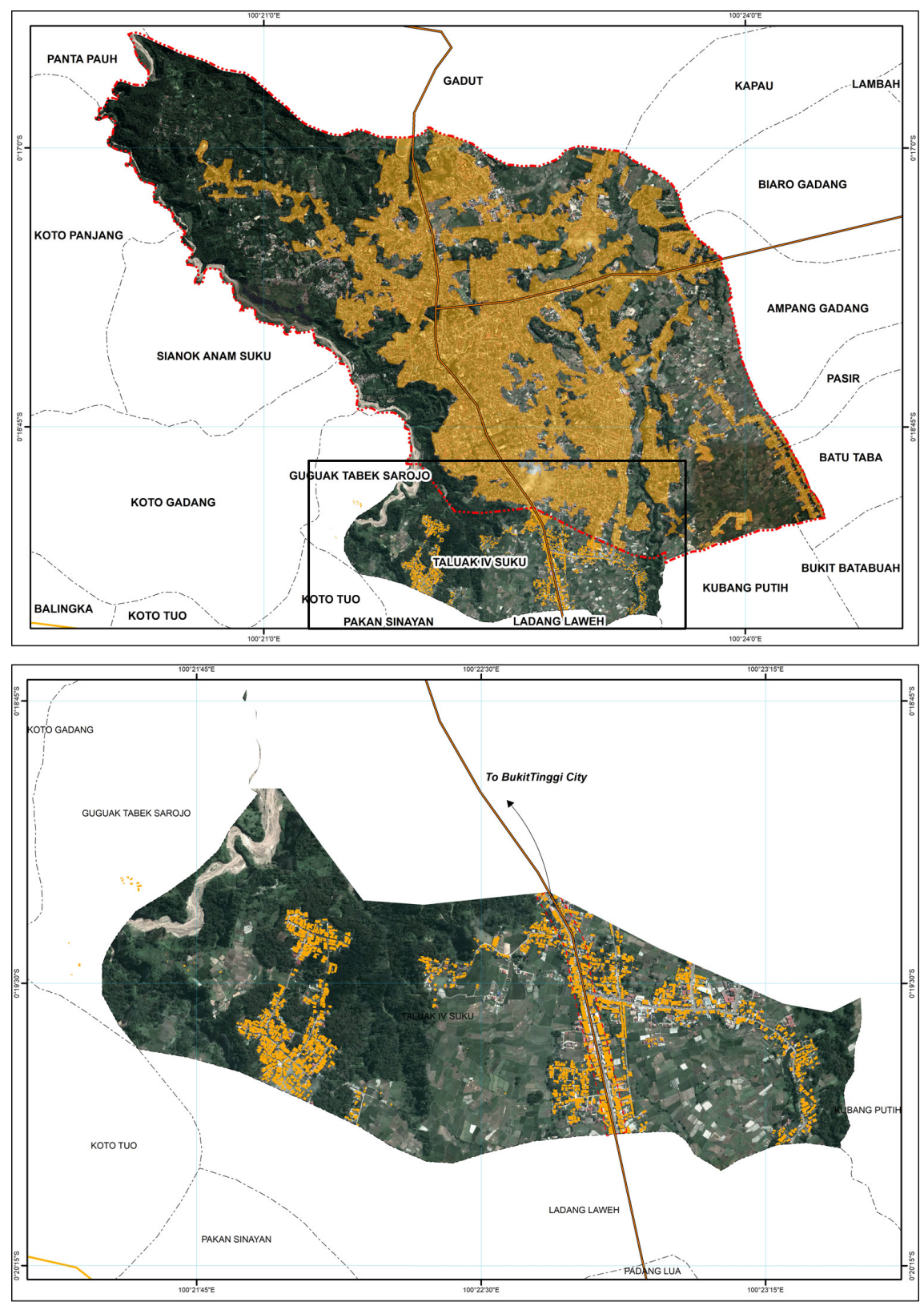

FIGURE 4B Bukittinggi expansion and built-up area in Taluak IV Suku, 2016 DIGITIZED FROM BING MAPS SATELLITE IMAGE IN 2016-2017 


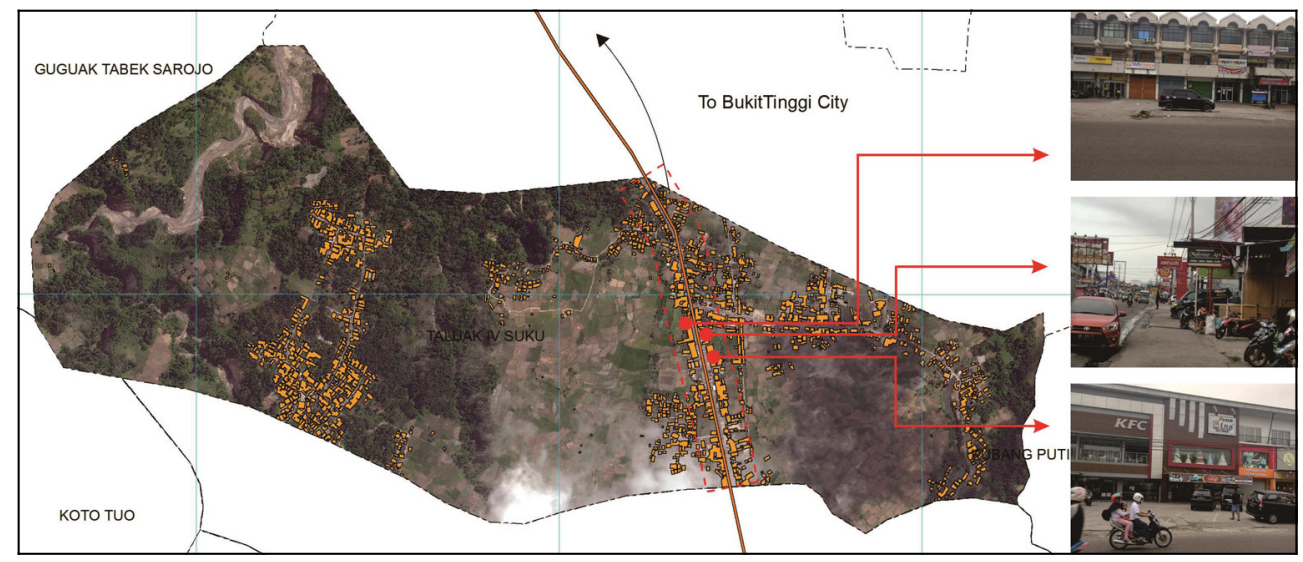

FIGURE 5 Built-up area of national transport corridor at Taluak IV Suku PERSONAL DOCUMENTATION 2019

tanah ulayat is acquired in the public interest, the owner is eligible for compensation in the form of replacement land, resettlement, or another form of compensation agreed between the community, the ninik mamak, and the chief of the tribe or by the Kerapatan Adat Nagari (KAN, Village Customary Council).

The customary-land ownership transfer procedure requires the release of the customary land right to the government. Subsequently, the government issues another type of ownership right, for example, the hak pakai (right to use) or the hak pengelolaan (right to cultivate). However, some people object to this practice, because they think that the ownership conversion turns what should be community-owned land into individually owned land. This then makes it difficult for the community to control the use of the land. Tanah ulayat is the heritage of a community or families in a kin group; it is owned by the community and managed by the ninik mamak. Thus, the release of the ownership rights as well as the conversion of the land-for example, from agricultural to urban use-must be discussed with the ninik mamak and the female owners of the land before it can be legalized by the KAN. Today, land-use conversions must be in line with the Spatial Plan

The KAN plays an important role in the ownership conversion process. If tanah ulayat is to be sold, according to unwritten law, the buyer must be 'sekaum, sesuku, sekampung, senagari, selaras, seagama, dan seterusnya' (from the same clan, tribe, village, idea, religion, and so on).

There is a saying in Minangkabau: Ayam gadang indak batalua, meaning 'the rooster lays no eggs'; this refers to the essence of the matrilineal value system, which states that the child does not inherit property or positions of socio-political authority from his father but only from his mother or from rel- 
atives in his mother's kin group (Benda-Beckmann 1982). Therefore, if there is no daughter in the family, they cannot bequeath their property. Meanwhile, the Minangkabau have long been noted for both a high level of voluntary outmigration and the tradition of eventually returning home, known as merantau (Maude 1979; Kato 2005; Naim 1984). Minangkabau culture encourages the man to merantau, to leave their house and even their village to earn a living, resulting in an unbalanced demography with very few or even no young men in some villages. In both cases, the tanah ulayat should be given up to the community to be managed. However, mostly for monetary reasons, those who have no daughter think that it would be more beneficial for them to sell the land rather than give it back to the community. There is also a religious (Islamic) reason for selling the land. ${ }^{15}$ Rather than giving back the land, it would be sold and the profits divided according to the Islamic law of inheritance.

The conversion from tanah ulayat to land with a modern ownership status is practised by both the original owners and those who have bought the land, while land-use conversions are also carried out by the original owners and by those who have bought or who rent the land. In any case, financial gain is the main reason for the land's conversion. According to the KAN, which screens potential buyers, the buyers of tanah ulayat in Taluak are mostly from Bukittinggi, and they are 'sekaum, sesuku, sekampung, senagari, selaras, seagama'. However, according to one respondent, there was one case where the actual buyer was a non-Muslim who provided the funds for a Muslim to buy tanah ulayat. This incident has made the community question the conversion process. The interview revealed that a change in the ownership will automatically convert the land-use category into land that can be used for trades and services, due to the unsound regulations governing land conversions from adat land to land governed by modern ownership regulations. This situation is aggravated by the apparent degradation of matrilineal values. ${ }^{16}$

The fact that the number of land and ownership conversions in Taluak is increasing, particularly along the road corridors, despite the lengthy land conversion procedure, begs the question of whether the ulayat system is capable of resisting land conversions for urban expansion.

15 Islamic inheritance law stipulates that, in general, sons will inherit more than daughters; see also the discussion on religion and identity in Benda-Beckmann and Benda-Beckmann (2012).

16 In 2016, a prominent local newspaper reported that there have been changes in the social strata in the Minangkabau community. See 'Pusako bak Simalakama bagi Niniak Mamak di Minang', Harian Haluan.com, 26-2-2016. 
Hans-Dieter Evers (1975) asserted that there are three basic types of land tenure in West Sumatra: (1) land held by individuals under individual-ownership rights; (2) land held by descent groups of varying size and generational depth under communal-ownership rights; and (3) land held by local groups, namely village communities. A survey of the landowners in Taluak IV Suku revealed that most of the land tenures along the arterial road have been converted into individual tenures ( $h a k$ milik), despite the lengthy conversion process. There are 288 ruko (shop houses) along the road according to data obtained from the Medium-Term Development Plan for Taluak IV Suku. ${ }^{17}$ Most of them are individually owned, having been converted from tanah ulayat ownership. Figure 4 shows the land use and administration of customary land in Taluak. The management of these three categories of tanah ulayat must involve the Ninik Mamak the KAN, and the Badan Pertanahan Nasional—BPN (National Land Agency). Categories 2 and 3 mostly occur along the national transport corridor and other major road corridors. Figure 6 shows the sequence.

Theoretically, according to adat law, category 1 land, that is, land used for settlements and agriculture, can be neither sold nor pawned. In reality, due to economic pressure, some category 1 land located close to the road has been converted from agricultural use to trades-and-services use. The conversion of category 1 land for other uses, which also requires a change in the land tenure from customary to individual land tenure, is not new and has been happening since colonial times. The Doenia Achirat newspaper reported on such changes in Padang as early as $1924 .{ }^{18}$ According to the datuk ${ }^{19}$ interviewed for this study, it was precisely to prevent such transfers to individual ownership that sale of the land was only possible under the conditions mentioned above. It has become clear, however, that in reality these restrictions on sale are often circumvented.

The conversion of customary land to individually owned land is also found in Taluak (see Tables 1 and 2) but occurs at a much slower pace than in Padang, where most of the tanah ulayat has been converted to individually owned land (Colombijn 1992, 2006). Land tenure rules are more stringent in Taluak, which lies at the heart (darek) of the former Pagaruyung kingdom of the Minangkabau.

17 Peraturan Nagari Taluak Iv Suku, Nomor 6 Tahun 2017 tentang Rencana Pembangunan Jangka Menengah Tahun 2017-2023.

18 'Marilah memikirkan masa yang akan datang', Doenia Achirat, 20-11-1924.

19 One of the highest ranks among tribal leaders. 


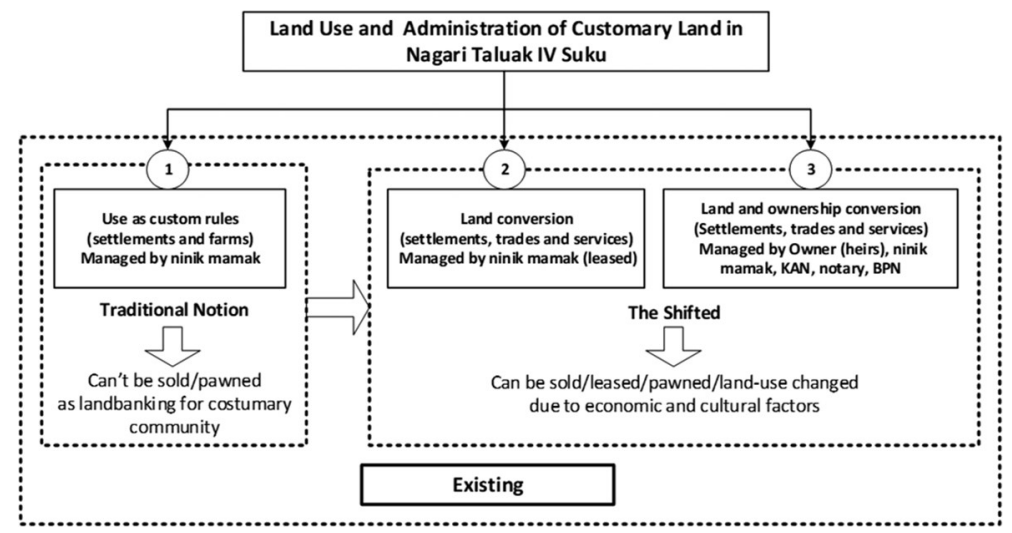

FIGURE 6 Land use and administration of customary land in Taluak IV Suku

Documents that record the conversion of land in Taluak show that acceptable reasons to sell the land were: (1) there were no more descendants of the kaum (clan); or (2) funds were needed to pay for wedding expenses, medical treatment, tuition fees, or other needs (Irza and Syabri 2016). These reasons are different from the historical ones of which the datuk spoke.

In Taluak, land-use conversion and ownership transfer are conducted through a lengthy process that includes several steps (see Figure 5):

- Led by the ninik mamak, the kinship group discusses the intention to convert their tanah ulayat from land used for agricultural purposes to land used for commercial purposes to gain more economic value from it. They will typically discuss the price and the distribution of the land.

- Once the group has reached an agreement on the distribution of the land, the ninik mamak will offer their tanah ulayat to investors for a negotiation. However, the decision on the agreement will be made by the kinship group. - The land transaction must be reported to the KAN and the National Land Agency to be legally certified.

Tanah ulayat that has been converted to commercial use will have an individual-ownership status, meaning that there is no longer a communal right to the land. In Taluak, this type of land is mostly (98\%) used for trades and services and located along the arterial road. Figures 7 and 8 show the land ownership transfer process.

Some respondents noted that there are cases in which the ninik mamak act unilaterally, selling the tanah ulayat for commercial uses without community consent. This is illegal and is considered criminal fraud, and thus the transaction can be cancelled by the court. Depending on the view taken, this lengthy conversion process, on the one hand, could be seen as a way to hinder the 


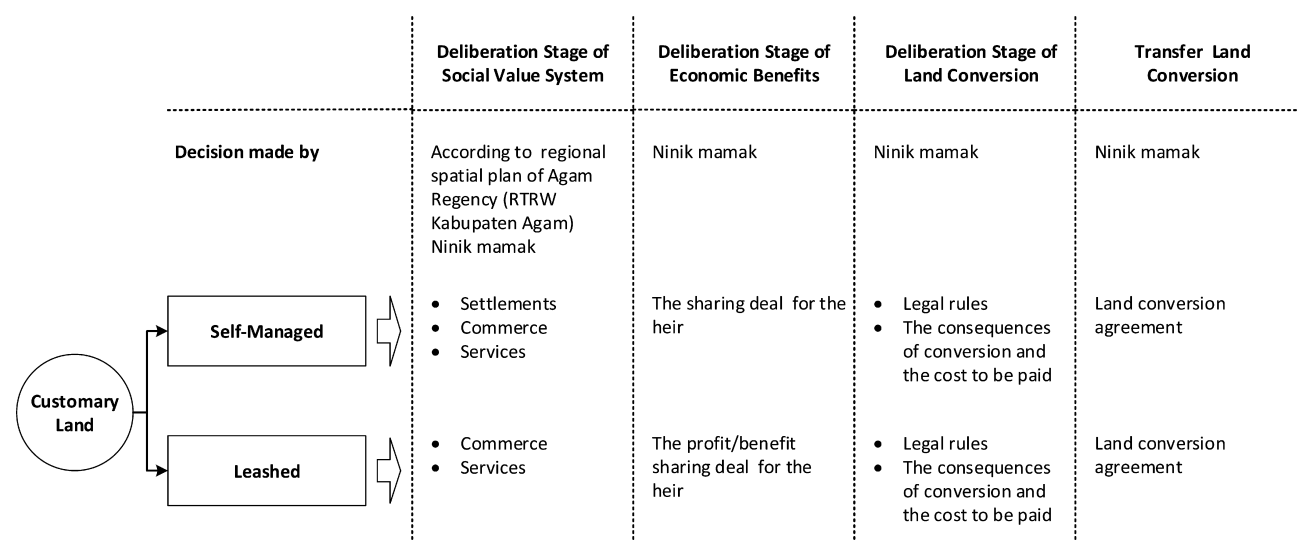

FIGURE 7 Land-use conversion process in Taluak IV Suku MODIFIED FROM AZMAN 2014

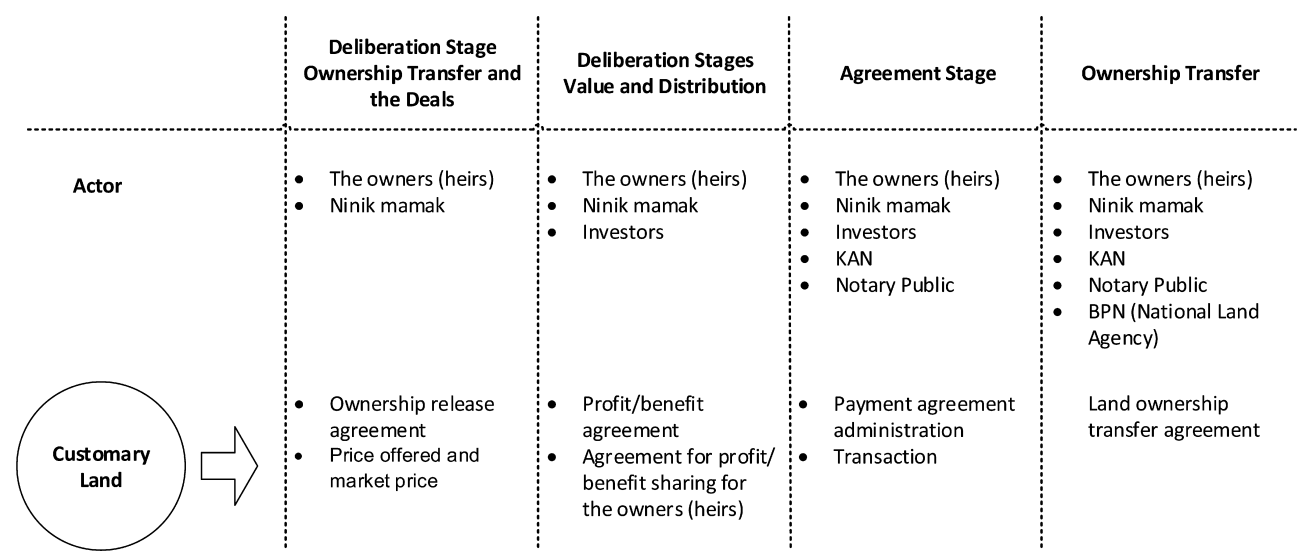

FIGURE 8 Ownership Transfer process in Taluak IV Suku

MODIFIED FROM AZMAN 2014

encroachment of Bukittunggi into communal land in Taluak; on the other, it could be seen as a hurdle to urban development, which needs the land for commercial use. A respected local newspaper reported that investors are complaining that the absence of complete data on tanah ulayat in West Sumatra has reduced the opportunities for investment, as investors need the data to be able to see these opportunities; ${ }^{20}$ a similar complaint was also raised by the business people we interviewed.

20 'Investor berharap tanah ulayat didata', Harian Haluan.com, 19-4-2017. 
The expansion of Bukittinggi into its peri-urban areas has arguably influenced how the community views the communal ownership of land. Tanah ulayat, as reserved land, has been sold, pawned, and leased for monetary benefit. For some, particularly the educated younger generation, monetary gain is seen as the way to achieve modernization. This generation complains that customary land ownership constrains land development. Other voices among the community argue that the matrilineal culture is not in line with Islamic teachings on inheritance (see also Benda Beckmann and Benda Beckmann 2012). This emergent Islamic interpretation of appropriate heritage rules has replaced the old paradigm of heirloom wealth, in which a kin group would lose its territory if the wealth was sold (Achir 2011). Conversely, for the older generation, tanah ulayat ownership is important, because it unites the community. With this in mind, the community could still acknowledge families living abroad that still have right to the tanah ulayat.

\section{Concluding Remarks}

This article aimed to discuss the role of customs and culture in land-use conversion in the peri-urban region of the fast-growing small city of Bukittinggi. The expansion of Bukittinggi has caused Taluak to undergo an unavoidable process of urbanization and the conversion of tanah ulayat. Most of the land-use conversion has been followed by a transfer of ownership rights, causing the tanah ulayat to become individually owned. This process is largely centred on the arterial road connecting Bukittinggi and Padang, the capital city of West Sumatra. Land-use conversion and the transfer of land ownership are practised by both the original, or the first, owners and by the secondary owners who bought the tanah ulayat for the primary reason of financial gain.

The culture and customary regulations concerning land ownership in Taluak slow the conversion process due to the lengthy deliberation process carried out by the ninik mamak before selling and converting the use and the ownership rights of the land. This is holding back the urbanization process in this periurban area. This was particularly visible when some of the communities and the ninik mamak of Taluak formally resisted the expansion of Bukittinggi that was stipulated in Government RegulationNo. 84 in 1999. The informal expansion of Bukittinggi and, thus, the urbanization of the peri-urban area continue to be less rapid than expected, with a conversion rate of $0.625 \%$ per year. Nevertheless, at this speed, it is estimated that within ten years the peri-urbanization of Taluak will be more visible as a result of the conversion of 24,699 ha of agricultural land for non-agricultural use. 
The growing pressure for land development, which increasingly sees land in terms of its economic value, has forced the privatization of communal land through leasing, pawning, or even selling. The privatization of customary land will continue as long as there is an increasing need for land for urban uses that would increase the economic value of the land. This situation is reinforced by the growing discourse that the customary land law is not in line with the Islamic law of inheritance. Benda Beckmann and Benda Beckmann (2004) noted that pawning and redemption have become the predominant way of gaining access to land; this is particularly true for the land along the arterial road connecting Bukittinggi and Padang Luar. This more capitalistic way of looking at land, which recent studies (Darwin, Safitri, and Zulkaidi 2016, 2017) have found to be increasingly widespread, has arguably eroded the traditional view of land as having social and environmental value.

\section{Acknowledgements}

The authors owe a huge debt to the individuals, ninik mamak, experts, and colleagues who were willingly interviewed for this study. Our gratitude also goes to Iт в for the Р3MI Research Grant 2017 that made this study possible.

\section{References}

Achir, M. (2011). Menelusuri jejak sejarah Nagari Kurai beserta lembaga adatnya. Bukittinggi: Kristal Multimedia.

Akrofi, E.O. (2013). Assessing customary land administration systems for periurban land in Ghana. [Unpublished doctoral dissertation, University of Cape Town.]

Allen, A. (2003). 'Environmental planning and management of the peri-urban interface (PUI): Perspectives on an emerging field', Environment and Urbanization 15-1:135-47. Asri, Z. (2001). 'Bukittinggi 1945-1980: Perkembangan kota secara fisik dan hubungannya dengan pemilik tanah'. [Unpublished master's thesis, Magister Humaniora Program, Pascasarjana Bidang Ilmu Pengetahuan Budaya, Universitas Indonesia, Depok.]

Azman, F. (2014). Keputusan masyarakat adat terhadap tanah ulayat dalam pasar lahan; Studi kasus: Masyarakat adat di kota Padang dan kota Payakumbuh, Sumatera Barat. [Unpublished dissertation, Program Studi Perencanaan Wilayah dan Kota, Institut Teknologi Bandung.]

Benda-Beckmann, F. von. (1982). ' "Ayam gadang toh Batalua?" Changing values in Minangkabau property and inheritance law and their relation to structural change', 
Newsletter 10-27:26-38. [Indonesia Circle, School of Oriental \& African Studies.] https://doi.org/10.108o/o3o62848208723855.

Benda-Beckmann, F. von and K. von Benda-Beckmann (2004). Struggles over communal property rights and law in Minangkabau, West Sumatra. München: Max Planck Institute. [Working Paper No. 64.]

Benda-Beckmann, K. von and F. von Benda-Beckmann (2012). 'Identity in dispute: Law, religion, and identity in Minangkabau', Asian Ethnicity 13-4 (September):341-58. DOI:10.1080/14631369.2012.710073.

B PS (2015). Provinsi Sumatera Barat dalam angka 2015. Padang: Badan Pusat Statistik. [BPs Catalogue 1102001.13.]

в PS Indonesia (2010). Kewarganegaraan, suku bangsa, agama, dan bahasa sehari-hari penduduk Indonesia. Hasil sensus penduduk tahun 2010. Jakarta: в PS Indonesia. [в P S Catalogue 2102032.]

B PS Sumbar (2017). Provinsi Sumatera Barat dalam angka 2017. Padang: Badan Pusat Statistik. [BPS Catalogue1102001.13.]

Bryant, C.R., L.H. Russwurm, and A.G. McLellan (1982). The city's countryside: Land and its management in the rural-urban fringe. New York: Longman.

Colombijn, F. (1992). 'Dynamics and dynamite: Minangkabau urban landownership in the 199os', Bijdragen tot de Taal-, Land- en Volkenkunde 148-3/4: 428-64.

Colombijn, Freek (2006). Paco-paco (kota) Padang: Sejarah sebuah kota di Indonesia abad ke-2o dan penggunaan ruang kota. Yogyakarta: Ombak.

Darwin, I., H. Winarso Safitiri, and D. Zulkaidi (2016). 'Peranan tanah ulayat sebagai land banking dalam perkembangan kota Bukittinggi'. [Paper presented at the ASPI National Seminar 'Perencanaan Pembangunan Inklusif Desa Kota', Padang, 25 November.]

Darwin, I., H. Winarso Safitri, and D. Zulkaidi (2017). 'Managing land expansion from neighboring city: The case of Nagari Taluak and Bukittinggi City'. [Paper presented at the international seminar 'Innovation of Rural Development for Implementing Sustainable Development Goals', Yogyakarta, Universitas Gajah Mada, 16-17 May.]

Evers, H.-D. (1975). 'Changing patterns of Minangkabau urban land-ownership', Bijdragen tot de Taal-, Land- en Volkenkunde 131-1:86-110.

Gershenberg, I. (1971). 'Customary land tenure as a constraint on agricultural development: A re-evaluation', East African Journal of Rural Development 4-1:51-62.

Harian Haluan (2017) 'Investor berharap tanah ulayat didata', Harian Haluan.com, 194-2017. https://www.harianhaluan.com/news/detail/64615/investor-berharap-tana h-ulayat-didata (accessed 30-1-2019).

Hadjerat, M. (1947). Sedjarah Negeri Kurai V Djorong serta pemerintahannja: Pasar dan kota Bukittinggi. Bukittinggi: тs. Ichwan в т.

Hamidi, H., et al. (2015). Indeks Desa Membangun 2015. Jakarta: Kementerian Desa, Pembangunan Daerah Tertinggal dan Transmigrasi. 
Hudalah, D., H. Winarso, and J. Woltjer (2007). 'Peri-urbanisation in East Asia: A new challenge for planning?', International Development Planning Review 29-4:503-19.

Irza, H. and I. Syabri (2016). 'Faktor penyebab perubahan guna lahan di jalan lingkar utara Kota Padang Panjang', Jurnal Pembangunan Nagari 1-2:53-73.

Kato, T. (2005). Alam Minangkabau dan merantau dalam perspektif sejarah (Pertama). Jakarta: Balai Pustaka.

Knight, R.S. (2010). Statutory recognition of customary land rights in Africa: An investigation into best practices for lawmaking and implementation. Rome: Food And Agriculture Organization of the United Nations.

Maude, A. (1979). 'How circular is Minangkabau migration?', The Indonesian Journal of Geography 9-37:1-12.

McGee, T.G. (1991). 'The emergence of desakota regions in Asia: Expanding a hypothesis', in: N.J. Ginsburg, B. Koppel, and T.G. Mc Gee (eds), The extended metropolis: Settlement transition in Asia, pp. 3-26. Honolulu: University of Hawai'i Press.

McGee, T.G. (2014). 'The emergence of desakota regions in Asia: Expanding a hypothesis', in: N.J. Brenner (ed.), Implosions/explosions: Towards a study of planetary urbanization, pp. 121-137. Berlin: Jovis.

Mugambwa, J.O. (2007). 'A comparative analysis of land tenure law reform in Uganda and Papua New Guinea', Journal of South Pacific Law 11-1:39-55.

Naim, M. (1984). Merantau: Pola migrasi suku Minangkabau. Yogyakarta: Gadjah Mada University Press.

Nas, P.J.M.(1984). Kota diDunia Ketiga:Pengantar sosiologikota.Jakarta: Bhaatara Karya Aksara.

Navis, A. (1984). Alam takambang jadi guru: Adat dan kebudayaan Minangkabau. Jakarta: Grafiti.

Nkawe, B. (2006). Conceptual framework for modelling and analysing periurban land problems in Southern Africa. [Unpublished PhD dissertation, University of New Brunswick.]

Pradoto, W. (2012). Development patterns and socioeconomic transformation in periurban area. Berlin: Technische Universität Berlin.

Russwurm, L.H. (1975). 'Urban fringe and urban shadow', in: R. Bryfogle and R.R. Krueger (eds.), Urban problems, pp. 148-64. Toronto: Holt, Rinehart, and Winston.

Simon, D. (2004). 'The changing urban-rural interface of African cities: Definitional issues and an application to Kumasi, Ghana', Environment \& Urbanization 16-2:23548. https://doi.org/10.1177/o9562478040160o214.

Soegijoko, B.T.S. and T. Firman (2005). 'Urbanisasi dan Pembangunan Perkotaan di Indonesia', in: Buku 1. Bunga Rampai Pembangunan Kota Indonesia dalam Abad 21: Konsep dan Pendekatan Pembangunan Perkotaan di Indonesia, pp. 86-95. Jakarta: Urban and Regional Development.

Sudrajat, S. (2016). 'Farmers' commitment in maintaining wetted land ownership status 
in peri-urban area of Yogyakarta', Indonesian Journal of Geography 48-1:91-101. https://doi.org/10.22146/ijg.1249o.

Sukot, S. (2010). 'Downplaying defects in state-systems and overemphasizing customary land tenure conversion for development in Papua New Guinea', in: T. Anderson and G. Lee (eds), In defence of Melanesian customary land, pp. 5-10. Sydney: AID/WATCH.

Surya, B. (2016). 'Change phenomena of spatial physical in the dynamics of development in urban fringe area', Indonesian Journal of Geography 48-1:118-34. https://doi .org/10.22146/ijg.17628.

Sylivester, S. (2013). 'Land tenure reforms and investment in Tanzania'. [MA dissertation in Economics, University of Dar es Salaam, Tanzania.]

Tegnan, H. (2015). 'Legal pluralism and land administration in West Sumatra: The implementation of the regulations of both local and nagari governments on communal land tenure', The Journal of Legal Pluralism and Unofficial Law 47-2:312-23. https://doi.org/10.108o/o7329113.2015.1072386.

Webster, D. and L. Muller (2002). Challenges of peri-urbanization in the Lower Yangtze region: The case of the Hangzhou-Ningbo corridor. Stanford, CA: Asia/Pacific Research Center. Stanford University.

Winarso, H., D. Hudalah, and T. Firman (2015). 'Peri-urban transformation in the Jakarta metropolitan area', Habitat International 49:221-9.

Woltjer, J. (2014). 'A global review on peri-urban development and planning', Jurnal Perencanaan Wilayah dan Kota 25-1:1-16.

Yaping, W. and Z. Min (2008). 'Urban spill over vs. local urban sprawl: Entangling land-use regulations in the urban growth of China's megacities'. [Paper presented at the 44th IsOCARP Conference 'Entangling land-use regulations in China's urban growth', Dalian, China, September.] 